\title{
メンブラン・フィルター上に捕集した大気浮遊粉じん中の 金属元素の発光分光分析
}

\author{
杉前 昭好, 長谷川 利雄*
}

(1972 年 3 月 6 日受理)

\begin{abstract}
メンブラン・フィルター上に捕集した大気浮遊粉じん中のケイ素, 鉄, 亜鉛, アルミニウム, マグネ シウム, カルシウム, 鉛, マンガン, 銅, バナジウムの発光分光分析法を検討した. 試料フィルタ一を $5 \mathrm{~mm} \phi$ に打ち拔き, これを $6 \mathrm{~mm} \phi$ 黑鉛平端電極に載せる.メチルエチルケトンを滴下し, フィルタ 一を溶解, 粉じえを電極上に 分散させる. 乾燥したのち, $10 \mathrm{ppm}$ のコバルト内標準および $4000 \mathrm{ppm}$

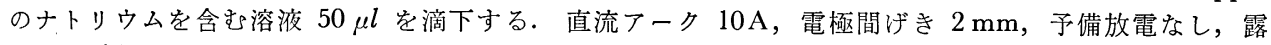
光時間 15 秒で励起発光し, 各種金属元素を定量した.

本法により，従来定量困難とされていた粉じん中のヶイ素，アルミニウム，刺鉛，カルシウムなど各 種金属元素の同時定量が可能となった.また試料成分の飛散，コンタミネーションなど分析誤差の原因 となる前処理操作を簡略化したため迅速かつ精度よく分析でき, 变動係数は 4.6〜 $14.4 \%$ であった.
\end{abstract}

\section{1 緒 言}

昭和 47 年 1 月 11 日環境庁より浮遊粒子状物質 (以 下浮遊粉じんと記す）に係る環境基準が公示され，浮遊 粉じんの定義, 環境基準値, 測定方法が示された. しか し浮遊粉じんを構成する名種成分については，標準的測 定方法は確立されておらず，したがって污染の実態は握 も立ちおくれているのが現状である. 著者らは浮遊粉じ ん構成成分測定の一環として, 既報に打いて, ガラス緎 維フィルター，万紙上に捕集した粉じん中の各種金属元 素について，その分析法を検討(1)2)，金属元素による 大気污染の実態を報告してきだ）最近粉じえ捕集用ろ 材としてガラス瀻維フィルターにかわって不純金属元素 の含有量の少ないメンブラン・フィルターが多く使用さ れるようになり4)，これによってガラス繊維フィルター に多量含まれていたため定量が困難とされていた亜鉛, ケイ素, アルミニウム, カルシウムなどの金属元素の定 量が可能となってきた. しかしメンブラン・フィルター 上に捕集した粉じえ中の金属元素定量についての確立さ れた方法は見あたらないようである，そこで著者らはメ ンブラン・フィルター上に捕集した粉じん中の各種金属 元素を発光分光分析法により定量するための諸条件の検

*大阪府公害監視センター：大阪市東成区中道 1 丁目
討を行なった。

浮遊粉じんを構成する金属元素としては，製鉄関係工 場からの鉄, マンガンなど, 石油系燃料の燃焼などに由 来する鉛, バナジウムなどが代表的污染質としてあげら れる.このほか砂ぼこりの舞い上がりによって，ケイ 素, アルミニウム, カルシウムなども浮遊している. 浮 遊粉じん中で，これらの土じょう成分の占める割合も高 く, 污染の機構解明のう光でも, 土じょう成分が大気污 染に及ぼす影響を 検討することが必要となってきた5)。 また浮遊粉じえを構成する金属元素の全分析を実施し, 工場地帯型, 商業地域型, 農村型などに浮遊粉じんをパ ターン分析することも要求されはじめている6).

以上の考察に基づき, 著者らは測定対象元素としてケ イ素, 鉄, 亜鉛, アルミニウム, マグネシウム, カルシ ウム, 鉛, マンガン, 銅, バナジウムを選び, これら金 属元素の同時定量法を確立するため種々検討を行ない, 感度, 精度においてもじゅうぶえ満足できる結果を得た ので以下に報告する.

\section{2 装置および試薬}

分光器 : エバート型回折格子分光写真器 GE-170 (島 津製), 回折格子 1200 本 $/ \mathrm{mm}$, 分散度 $4.8 \AA / \mathrm{mm}$ (1 次). 
発光装置: モジュラーソース 280000 (島津製), 直流 アーク, 整流高压スパーク.

測光装置：ミクロホトメーター JM-3（日本ジャーレ ル・アッシュ製).

電極：分光分析用 $6 \mathrm{~mm} \phi$ 黑鉛電極（ナショナル・カ 一ボン製), $7 \mathrm{~mm} \dot{\phi}$ 高純度銅電極（ジョンソン・マッセ イ製), $6 \mathrm{~mm} \phi$ グラッシー・カーボン電極（東海電極 製).

乾板: Kodak SA-1.

標準列溶液 : 各分析元素の高純度金属, 試薬特級塩化 物あるいは硝酸塩を精密分析用塩酸および硝酸に溶解す る.ケイ素については試薬特級二酸化ケイ素を 6 倍量の 炭酸ナトリウムと混合，白金るつぼで融解したのち，融 体を塩酸に溶解する。調製した金属元素溶液を適宜希 釈, 内標準元素コバルトを $10 \mu \mathrm{g} / \mathrm{m} l$ になるように添加 し, さらに炭酸ナトリウム水溶液 $(60 \mathrm{mg} / \mathrm{ml})$ を溶液 中のナトリウム濃度が $4000 \mu \mathrm{g} / \mathrm{ml}$ になるように添加す る.

内標準元素溶液：高純度金属コバルトを塩酸に溶解す る. 使用時にコバルト濃度が $10 \mu \mathrm{g} / \mathrm{m} l$ になるように希 釈する.また炭酸ナトリウム水溶液も添加し, ナトリウ ム濃度が $4000 \mu \mathrm{g} / \mathrm{ml}$ となるように調製する.

標準列溶液, 内標準元素溶液はポリエチレン製容器に 保存した。その他実験に使用した試薬はいずれも市販特 級品を用いた。

浮遊粉じえ試料：ろ紙ホールダー（ザルトリウス製 $\mathrm{SM}$ 16212) に $47 \mathrm{~mm} \dot{\phi}$ メンブラン・フィルター（ザ ルトリウス製 SM 11304, 材質：セルローズナイトレー ト，ポアサイズ: $0.8 \mu)$ を取り付ける. 試料大気を空 気吸引流量 $30 \mathrm{l} / \mathrm{min}$ で吸引, ろ過し, フィルター上に 浮遊粉じえを捕集する。試料採取時間は 8 時間または 24 時間である.

\section{3 分析操作}

試料フィルターを $5 \mathrm{~mm} \phi$ に打ち抜き，これを $6 \mathrm{~mm} \phi$ 黒鉛平端電極上に載せる. この上にメチルエチルケトン (MEK) を約 $10 \mu l$ 滴下し, メンブラン・フィルター を溶解する. 乾燥したのち，フィルターの溶解を完全に するため, 再度 MEK $10 \mu l$ を滴下する. 内標準元素 溶液 $50 \mu l$ をミクロピペットにより, 滴下, 乾燥し, 試 料電極とする. 標準列試料電極は平端電極に $5 \mathrm{~mm} \phi$ に 打ち抜いた未使用メンブラン・フィルターを載せ，試料 電極と同様の処理をしたのち，標準列溶液を $50 \mu l$ 滴下

Table I Experimental conditions

\begin{tabular}{ll} 
Excitation source & $:$ DC arc \\
Current & $: 10 \mathrm{amp}$. \\
Analytical gap & $: 2 \mathrm{~mm}$ \\
Pre-arc time & $: 0 \mathrm{sec}$ \\
Exposure time & $: 15 \mathrm{sec}$ \\
Slit width & $: 25 \mu$ \\
Step filter & $: 3 \mathrm{step}$ filter \\
& (Transmission; 4, 20, 100\%) \\
\hline
\end{tabular}

して作製する．作製した電極を $6 \mathrm{~mm} \phi 90^{\circ}$ 円すい黒鉛 電極を対極として, Table I の分析条件により, 放電発 光させ, Table II の分析線対により各種金忠元素を定 量, さらに空気吸引流量などより $1 \mathrm{~m}^{3}$ 空気中の金属元 素量を算出する.

Table II Analytical line pairs
$\mathrm{Si}(\mathrm{I}) \quad 2881.578 \AA / \mathrm{Co}(\mathrm{I}) 3044.005 \AA$
$\mathrm{Fe}$ (I) $3037.388 \AA / \mathrm{Co}(\mathrm{I}) \quad 3044.005 \AA$
$\mathrm{Zn}(\mathrm{I}) \quad 3345.020 \AA / \mathrm{Co}$ (I) $3044.005 \AA$
$\mathrm{Al}(\mathrm{I}) \quad 3082.155 \AA / \mathrm{Co}(\mathrm{I}) \quad 3044.005 \AA$
$\mathrm{Mg}$ (I) $2779.834 \AA / \mathrm{Co}$ (I) $3044.005 \AA$
$\mathrm{Ca}$ (II) $3179.332 \AA / \mathrm{Co}$ (I) $3044.005 \AA$
$\mathrm{Pb}$ (I) $2833.069 \AA / \mathrm{Co}(\mathrm{I}) \quad 3044.005 \AA$
$\mathrm{Mn}$ (I) $2798.271 \AA / \mathrm{Co}$ (I) $3044.005 \AA$
$\mathrm{Cu}(\mathrm{I}) \quad 3247.540 \AA / \mathrm{Co}(\mathrm{I}) \quad 3044.005 \AA$
$\mathrm{V}$ (I) $3185.396 \AA / \mathrm{Co}$ (I) $3044.005 \AA$

\section{4 定量条件の検討および結果}

\section{1 メンブラン・フィルターの溶解}

メンブラン・フィルター上に捕集した粉じん中の金属 元素を定量するための試料前処理法としては, 硝酸, 硝 酸一過塭素酸により金属元素を抽出する方法7)8)，フィル ターや粉じん中の有機物を低温兏化装置により死化した のち塩酸に溶解する方法 ${ }^{9}$, 温アセトンによりフィルタ 一を溶解したのち硝酸に溶解する方法10)などが報告され ている. しかし公害分析で要求される迅速性に欠け, 試 料前処理時におけるコンタミネーション, 金属元素の酸 への溶解性などの問題点がある.

著者らはこれらの問題点を解消するため, 試料フィル ターを直接電極上に載せ，これを放電発光させ，粉じん 中の金属元素を迅速分析しょうとした. しかし放電の衝 撃によって，フィルターが電極上より飛び出すため，フ ィルター上の金属元素が完全に電極間げきに導入されな い欠点をもつ. またフィルターが電極上で然焼する場合 もあり，分析精度がわるい. そこでメンブラン・フィル ターの有機溶媒への溶解性を利用し, 電極上でフィルタ 一を溶解し，フィルター上に捕集した粉じんを電極上で 分散させることにより, 放電を安定化し, 分析感度, 精 度を上昇させようとした。

Fig. 1 は黒鉛平端電極に $5 \mathrm{~mm} \phi$ に打ち抜いた試料フ ィルターを載せ, アセトン, MEK, メチルイソブチル ケトン，アセチルアセトン，エタノール，ベンゼンを $10 \mu l$ 滴下, 乾燥したのち, Table I の分析条件で放電 発光させ, 得られたスペクトル線強度を比較したもので ある.なお，電極上のフィルターは，溶媒としてケトン 類を用いた場合，ほぼ溶解しており，エタノールではわ 


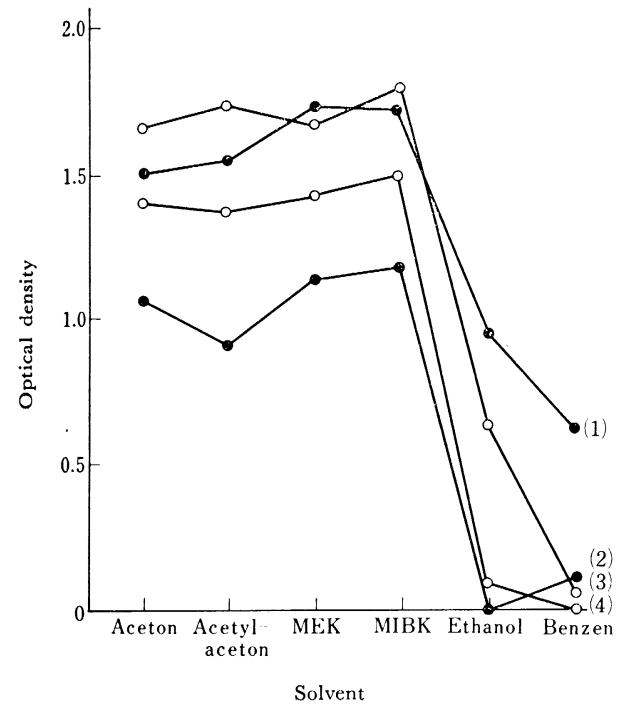

Fig. 1 Effect of dissolution of filter on the spectral line intensity

(1) $\mathrm{Mg}$ (I) $2779.834 \AA ; \quad$ (2) $\mathrm{Mn}(\mathrm{I}) 2798.271 \AA$; (3) $\mathrm{Si}(\mathrm{I}) 2881.578 \AA$; (4) $\mathrm{Fe}(\mathrm{I}) 3037.388 \AA$

ずかに膨潤する程度であり，ベンゼンではほとんど変化 をうけていない。

フィルターを電極上で溶解することによって，著しく スペクトル線強度が大となった。したがってフィルター 上の金属元素は円滑に放電間げきに導入されているもの と推測される。なお，フィルター溶解によって，電極表 面はフィルター溶解残さによって被覆されている. この ため内標準元素溶液, 標準列溶液を滴下した場合, 溶液 が電極内部に浸透していくことが少なく，溶液の大部分 は電極表面で蒸発しているものと考えられる. 以上より 試料電極は電極上で MEK により，フイルターを溶解 して調整するものとした. メンブラン・フィルターは数 社より市販されているが，材質がセルローズナイトレー トであれば，MEK に溶解する.

\section{2 励起法}

平端電極上でフィルターを溶解したのち，これを放電 励起する場合, 電極材質, 励起法に種々の組み合わせが 考えられる. 電極として黒鉛電極, グラッシー・カーボ ン電極，銅電極を選び， $90^{\circ}$ 円すい $6 \mathrm{~mm} \phi$ 黑鉛電極 を対極として, 直流アーク（電流值 $10 \mathrm{~A}$ ), 高圧整流又

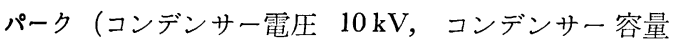
$0.007 \mu \mathrm{F} \times 2$ ， インダクタンス $50 \mu \mathrm{H})$ により励起し， スペクトル線強度を比較した. 結果の一部を Fig. 2 に
示す、ただし直流アーク，スパーク放電でスペクトル線 強度に著しい差異があり, 直流アークでは 3 段フィルタ 一の $4 \%$ 透過率部分，スパークでは $100 \%$ 透過率部分 のスペクトル線像を用いて比較した.

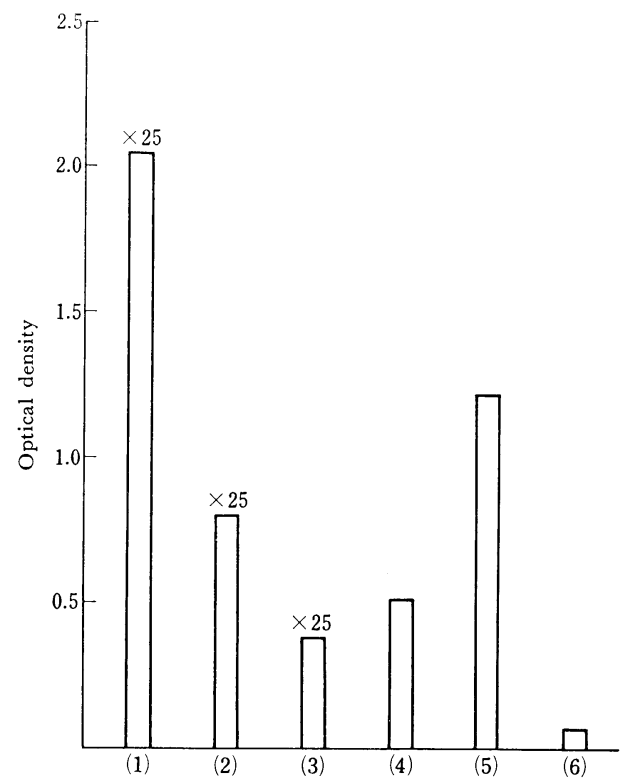

Fig. 2 Effect of electrode-excitation method on spectral line intensity

(1) Graphite-DC arc; (2) Glassy carbon-DC arc; (3) Copper-DC arc; (4) Graphite-spark; (5) Glassy carbon-spark; (6) Copper-spark; Spectral line: $\mathrm{Al}(\mathrm{I}) 3082.155 \AA$; (1), (2), (3) Measured at $4 \%$ transmission part of step filter; (4), (5), (6) Measured at $100 \%$ transmission part of step filter

黒鉛電極一直流アークの組み合わせが最もスペクトル 線強度が大であり，銅電極一スパーク放電が最もスペク トル線が弱い, 一方, Nachtrieb は銅スパーク法の検出

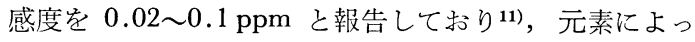
ては直流アークより高感度とされている. この相違の原 因として，電極上を被覆しているフィルター溶解残さが 金属元素の蒸発気化に影響を及ぼしているものと考えら れる．とこで銅電極および電極表面がフィルター溶解残 さによって被覆された銅電極にそれぞれ一定量の金属元 素溶液を滴下, 乾燥したのちスパーク放電した. Fig. 3 に 15 秒ごとに乾板を移動して作成したアルミニウム (分析元素)，銅（電極成分）の蒸発気化曲線を示す.な 抢, 滴下元素溶液中に硝酸が存在した場合, 電極を侵し て感度を下げるので11)12)，滴下溶液は塩酸溶液を用い た. 


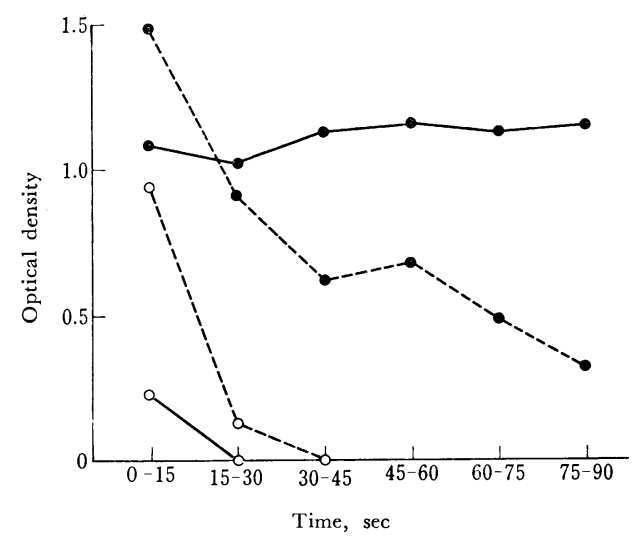

Fig. 3 Effect of filter residue on I-t curves Copper-spark : - - O - - Al(I) $3082.155 \AA$, - - - - $\mathrm{Cu}(\mathrm{I}) 3247.540 \AA$; Copper filter residue-spark : - $\mathrm{O}-$ $\mathrm{Al}(\mathrm{I}) 3082.155 \AA,-\bullet-\mathrm{Cu}(\mathrm{I}) 3247.540 \AA$

分析元素のスペクトル線は銅スパーク法が強く, 電極 成分のスペクトル線強度は電極上にフィルター溶解残さ が存在する場合に増大した。 また蒸発気化曲線も異なっ たものとなっており，金属元素の蒸発気化は明らかに銅 電極上のフィルター溶解残さの影響をうけている.

黒鉛電極を直流アークで励起した場合について，フィ ルター溶解残さが金属元素の蒸発気化に及ぼす影響を検 討した. フィルター溶解残さによって被覆された黒鉛電 極では，滴下した金属元素溶液は電極表面で濃縮されて いる. これに対し，黒鉛電極に金属元素溶液を直接滴下 した場合，溶液が電極内部まで侵透しており，電極上の フィルター残さの有無によって電極内の金属元素の分布 に明らかな差異がある.しかしこの電極を直流アークで 励起した場合, 蒸発気化曲線に変化はあるが, 電極内の 金属元素が完全に蒸発気化するまで露光すること（露光 時間 30 秒）によって，ほぼ近似したスペクトル線強度 が得られた. 以上より，黒鉛電極一直流アーク放電の組 み合わせが，電極上のフィルター溶解残さの影響が最も 少なく, また分析感度, 精度などからも, 最適の励起法 と考える.

\section{3 電流値および露光時間}

直流アーク電流值を 5, 10, $15 \mathrm{~A}$ に設定し, 電流值 が金属元素の蒸発挙動に及ぼす影響を検討した・結果の

1 例として, マンガンの時間一スペクトル線強度曲線を Fig. 4 に示す.

電流值 $10 \mathrm{~A}$ 以上では, 放電開始より 15 秒で金属元 素はほぼ完全に蒸発気化している，またスペクトル線が

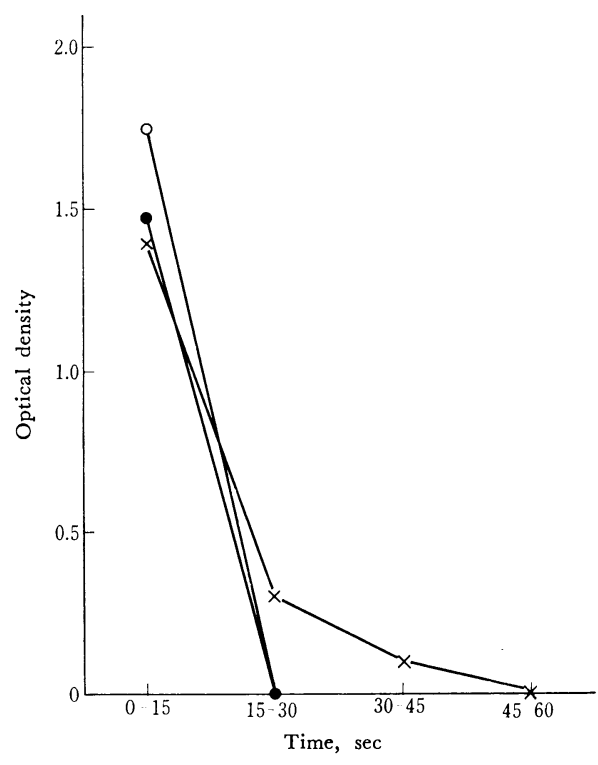

Fig. 4 Effect of arc current on I-t curves $\mathrm{Mn}(\mathrm{I}) 2798.271 \AA$; $\times 5 \mathrm{~A} ; 010 \mathrm{~A}$;

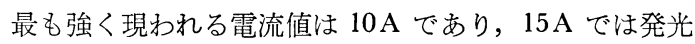
が不安定になる.なお，マンガン以外の金属元素につい ても，ほぼ同椂の傾向である. 以上の結果より, 電流值 $10 \mathrm{~A}$, 予備放電なし, 露光時間 15 秒とした.

\section{4 電極間げき}

間げきを $2 ， 3 ， 4 ， 5 ， 6 \mathrm{~mm}$ になるように変化させ, 電極間げきがスペクトル 線強度に 及ぼす影響を検討し た. 結果の一部を Fig. 5 に示す.

電極間げきが大きくなるにつれて，一般にスペクトル 線強度は減少の傾向を示す. しかしわずかであるが強度 増大の傾向をもつ元素もあり，その挙動は元素によって 異なる.ここでは放電の安定性を考虑して, 電極間げき は $2 \mathrm{~mm}$ とした.

\section{5 マトリックス効果について}

浮遊粉じん中には各種金属元素が混在しており, 共存 元素量も試料によって大幅に变動している. また第 3 元 素の共存によって, 分析元素のスペクトル線強度が著し い影響をうけることも，すでによく知られている.した がって, 実際試料を分析する場合, 共存元素の影響をじ ゅうぶん検討しておくことが必要である.そこで粉じん 中の存在量, イオン化電圧を考慮に入れ，ナトリウム， カルシウム, マグネシウム, 鉄, アルミニウム, 亜鉛が 共存した場合のスペクトル線強度に及ぼす影響を検討し 


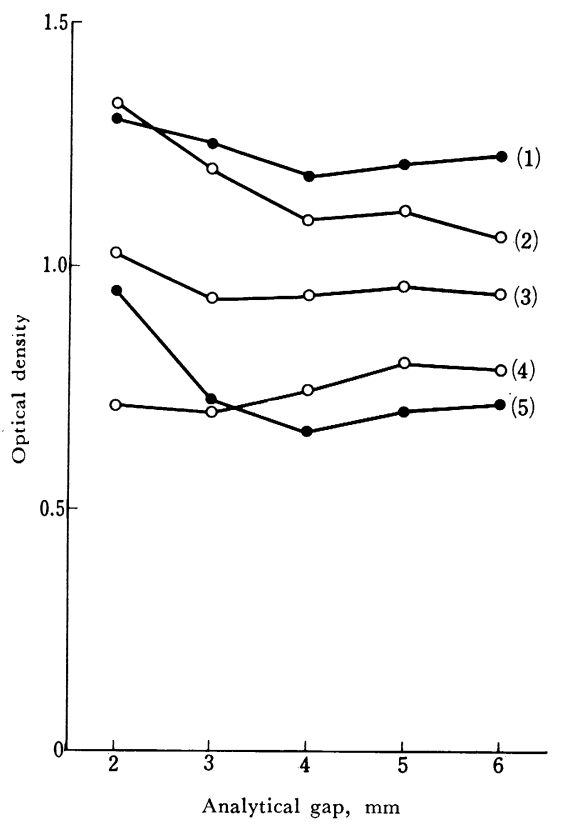

Fig. 5 Effect of analytical gap on the spectral line intensity

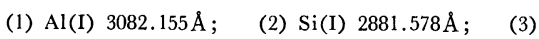
$\mathrm{Fe}(\mathrm{I}) 3037.388 \AA$; (4) $\mathrm{Mn}(\mathrm{I}) 2798.271 \AA$; (5) $\mathrm{V}(\mathrm{I})$ $3185.396 \AA$

た.

一定量の分析元素を含む溶液に各共存元素を段階的に 添加する. この溶液 $50 \mu l$ をンンブン・フィルターを 溶解した電極上に滴下，乾燥し，各分析元素のスペクト ル線強度の変化を調べた. 結果の 1 例としてマンガンの スペクトル線強度に及ぼす影響を Fig. 6 に示す. 共存 元素の添加によって, スペクトル線強度は著しく増大し

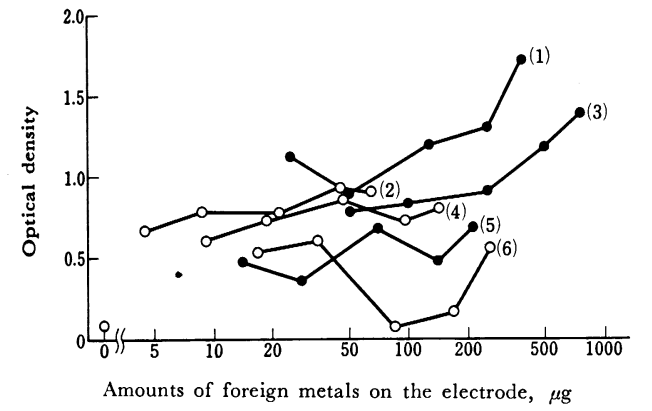

Fig. 6 Effect of foreign metals on the spectral line intensity

Mn(I) $2798.271 \AA$; (1) Calcium; (2) Magnesium; (3) Sodium; (4) Aluminum; (5) Zinc; (6) Iron
ており，マンガン以外の分析元素についてもほぼ同様の 傾向であった：これを利用して，電極上に共存元素を添 加することによって分析感度を高めることができる．ケ イ素溶液は二酸化ケイ素を炭酸ナトリウムで融解して調 製する関係で, 標準列溶液中には多量のナトリウムが溶 解している. したがって共存させる元素はナトリウムと し, 共存量は融片量, Fig. 6 の結果より $4000 \mu \mathrm{g} / \mathrm{ml}$ と した.これは電極上のナトリウム量に換算すると $200 \mu \mathrm{g}$ となる。

ナトリウムを一定量共存させることにより，さらに別 の元素が加わっても，スペクトル線強度はほとんど影響 をうけないことも明らかになった。 その様子を Fig. 7 に示す.

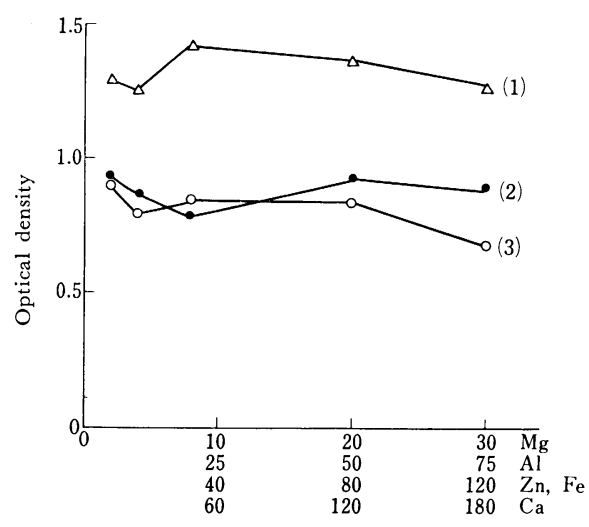

Amounts of foreign metals on the electrode, $\mu \mathrm{g}$

Fig. 7 Effect of foreign metals on the spectral line intensity

Amounts of sodium : $200 \mu \mathrm{g}$; $\quad$ (1) $\operatorname{Si}(\mathrm{I}) 2881.578 \AA$; (2) $\mathrm{Fe}$ (I) $3037.388 \AA$; (3) $\mathrm{Mn}(\mathrm{I}) 2798.271 \AA$

本法では粉じんを捕集したフィルターを電極上で溶解 し，粉じえを電極上で分散させ，これを試料電極として いる. そのため電極上には粉じん中の炭素質, 有機物, 種々の化学形態の金属元素およびフィルター溶解残さが 混在しており, これら共存物質が金属元素のスペクトル 線強度に及ぼす影響を検討しておく必要がある.

粉じんを捕集した試料フィルターを電極上で溶解した のち，低温灰化装置（Trapelo 製 LTA-504） 中で 30 分間灰化処理を行なって作製した電極および未処理電極 についてスペクトル線強度を比較した. 灰化処理によっ て, 粉じん中の炭素質, 有機物およびフィルター溶解残 さは灰化され，また金属元素の化学形態は酸化物などに 変化していると考えられる. しかしスペクトル線強度は 
粉じん灰化処理による影響をほとんどうけていない。 た金属元素の蒸発気化曲線も灰化処理電極, 未処理電極 についてほぼ類似している，したがって本法では兏化な どによってマトリックスを調整する必要はないものと考 える.

\section{6 検量線}

3 に述べた操作により作成した検量線を Fig. 8 に示 す. 各元素ともほぼ満足すべき 良好な検量線が得られ た. なお, 実際試料中の元素濃度, 分析線の感度などか ら，3段フィルターを使用し，ケイ素は 4\% 透過率部 分，アルミニウム，カルシウム，マンガン，銅は $20 \%$ 透過率部分, その他の元素は $100 \%$ 透過率部分のスペク トル線像を測定した。

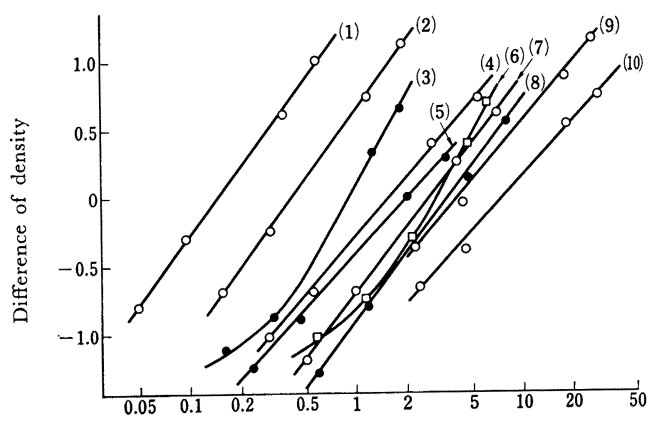

Amounts of metals on the electrode, $\mu \mathrm{g}$

Fig. 8 Working curves

(1) Vanadium; (2) Manganese; (3) Copper; (4) Magnesium; (5) Lead; (6) Zinc; (7) Aluminum; (8) Iron; (9) Silicon; (10) Calcium

\section{7 分析精度}

Fig. 8 に示した検量線を用いて同一試料フィルターに ついて 6 回のくりかえし分析を行ない，分析精度を調べ た結果を Table III に示す.

変動係数は 4.6〜14.4\% であり，ほぼ満足できる結 果が得られた。

\section{5 実際試料の分析}

本法による実際試料の分析結果を Table IV に示す. この結果より，本法は浮遊粉じん中の金属元素の迅速定 量法としてじゅうぶん利用できることがわかった。

\section{6 結 $\overline{\overline{\bar{~}}}$}

メンブラン・フィルター上に捕集された浮遊粉じん中 の各種金属元素の発光分光分析法を確立した. コンタミ
Table III Reproducibility

\begin{tabular}{|c|c|c|c|c|c|c|c|c|}
\hline \multirow{2}{*}{ Element } & \multicolumn{6}{|c|}{ No. } & \multirow{2}{*}{ Average } & \multirow{2}{*}{ C. V. $†$} \\
\hline & 1 & 2 & 3 & 4 & 5 & 6 & & \\
\hline $\mathrm{Si}$ & 11.4 & 12.4 & 12.7 & 11.8 & 11.4 & 11.8 & 11.9 & 4.6 \\
\hline $\mathrm{Fe}$ & 4.23 & 4.27 & 4.79 & 4.47 & 4.15 & 3.59 & 4.25 & 9.3 \\
\hline $\mathrm{Zn}$ & 1.86 & 1.61 & 1.70 & 1.67 & 1.50 & 1.88 & 1.70 & 9.1 \\
\hline $\mathrm{Al}$ & 2.54 & 3.10 & 3.47 & 2.84 & 3.00 & 2.34 & 2.88 & 14.4 \\
\hline $\mathrm{Mg}$ & 1.55 & 1.28 & 1.49 & 1.55 & 1.63 & 1.37 & 1.48 & 8.9 \\
\hline $\mathrm{Ca}$ & 4.27 & 3.38 & 3.95 & 4.14 & 4.14 & 4.14 & 4.00 & 8.0 \\
\hline $\mathrm{Pb}$ & 0.75 & 0.78 & 0.59 & 0.63 & 0.57 & 0.61 & 0.66 & 13.3 \\
\hline $\mathrm{Mn}$ & 0.47 & 0.54 & 0.54 & 0.48 & 0.52 & 0.41 & 0.49 & 10.4 \\
\hline $\mathrm{Cu}$ & 0.28 & 0.26 & 0.31 & 0.30 & 0.37 & 0.29 & 0.30 & 12.6 \\
\hline $\mathrm{V}$ & 0.10 & 0.10 & 0.13 & 0.14 & 0.11 & 0.14 & 0.12 & 14.4 \\
\hline
\end{tabular}

Unit : $\mu \mathrm{g} / M^{3} ; \quad \dagger$ C. V. : Coefficient of variation $\nu=\frac{100}{\bar{x}} \sqrt{\frac{\sum\left(x_{i}-\bar{x}\right)^{2}}{n-1}}$

Table IV Analytical results

\begin{tabular}{lccccc}
\hline \multirow{2}{*}{ Element } & \multicolumn{5}{c}{ Samplet no. } \\
\cline { 2 - 6 } & 1 & 2 & 3 & 4 & 5 \\
\hline $\mathrm{Si}$ & 8.82 & 33.4 & 50.4 & 16.6 & 26.7 \\
$\mathrm{Fe}$ & 3.27 & 7.93 & 9.34 & 7.73 & 13.0 \\
$\mathrm{Zn}$ & 0.82 & 1.18 & 2.07 & 2.17 & 1.82 \\
$\mathrm{Al}$ & 2.11 & 5.35 & 7.94 & 9.13 & 12.8 \\
$\mathrm{Mg}$ & 0.59 & 1.42 & 1.90 & 1.04 & 1.27 \\
$\mathrm{Ca}$ & 3.22 & 7.85 & 8.92 & 6.19 & 6.59 \\
$\mathrm{~Pb}$ & 0.52 & 0.89 & 0.94 & 1.45 & 1.22 \\
$\mathrm{Mn}$ & 0.30 & 1.48 & 1.03 & 0.52 & 0.40 \\
$\mathrm{Cu}$ & 0.14 & 0.39 & 0.32 & 0.24 & 0.22 \\
$\mathrm{~V}$ & 0.10 & 0.06 & 0.28 & 0.37 & 0.19 \\
\hline
\end{tabular}

Unit : $\mu \mathrm{g} / M^{3} ; \quad \dagger$ Samples collected at $10 \mathrm{~m}$ above the ground in a commercial area of Osaka

ネーション，分析元素の飛散など分析誤差の原因となる 試料前処理を簡略化し，試料フィルターを黒鉛平端電極 上でメチルエチルケトンにより溶解，フィルター上に付 着した粉じんを電極上で分散させたのち，内標準元素溶 液を滴下, 乾燥し, 試料電極とした. この電極を直流ア 一クで放電励起し，粉じん中の各種金属元素が迅速に， 精度よく定量できた．本法により，従来捕集用沪剤中の 含有量, 元素の酸への溶解性などの関係で測定が困難と されていたケイ素, アルミニウム, 亜鉛, カルシウム, マグネシウムなども定量できるようになり，浮遊粉じん 中の金属元素の全分析が可能となった. 本法は浮遊粉じ え中の金属元素の迅速定量法としてじゅうぶえ有用であ る.

\section{交献}

1) 長谷川利雄, 杉前昭好 : 本誌, 20, 840 (1971).

2) 長谷川利雄, 杉前昭好 : 同上, 20, 1406 (1971).

3) 長谷川利雄, 杉前昭好: 衛生化学, 17, 404(1971).

4) S. S. Hochheiser, F. J. Burman, G. B. Morgan : Environ. Sci. Technol., 5, 679 (1971). 
5) N. L. Morrow, R. S. Brief : ibid., 5, 786 (1971).

6) D. W. Lander, R. L. Steiner, D. H. Anderson, R. L. Dahm : Appl. Spectry., 25, 270 (1971).

7) R. H. Daines, H. Motto, D. M. Chico : Environ. Sci. Technol., 4, 319 (1970).

8) D. E. Allan, J. O. Pierce, D. Yeager : $A m$. Industr. Hyg. Assoc. J., 29, 469 (1968).

9）浜口 彰，伊東清志，今井佐金吾，宮田 勉，蒠 科宗博：日本分析化学会第 20 年会講演要旨集， p. B 130 (1971).

10) J. Y. Hwang, F. L. Feldman : Appl. Spectry., 24, 371 (1970).

11) N. H. Nachtrieb : "Principles and Practice of Spectrochemical Analysis", (1950), (McGrawHill).

12）小田仲彬：“工業発光分光分析”，(1966), (東京 化学同人).

$$
\hat{n}
$$

Emission spectrographic determination of trace metals in airborne particulates collected on a membrane filter. Akiyoshi Sugimae and Toshio Hasegawa (Environmental Pollution Control Center, Osaka Pref., Higashinari-ku, Osaka-shi)

A method was described for the spectrographic determination of silicon, iron, zinc, aluminum, magnesium, calcium, lead, manganese, copper and vanadium in airborne particulates, which were collected on a membrane filter.

Methods for the determination of elements in airborne particulates had usually involved dry, wet or low temperature ashing of filters, dissolution of elements in acids and concentration prior to analysis. However, all elements in airhorne particulates were not necessarily dissolved in acids and these sample preparation steps provided the oppotunities for sample contamination and loss of sample constituents. It was considered that direct discharge of the sample filter on the electrode solved these problems. But serious errors were resulted from flying off of filter from the electrode and burning of filter by striking of discharge on the filter.

So in this method, after dissolving the sample filter on the electrode by methyl-ethyl-ketone and dispersing airborne particulates, collected on the filter, at the surface of the electrode, the prepared electrode was discharged. As the results, spectral lines were intensified remarkably and were reproducible compared with direct discharge of filter. It could be considered that the elements on the filter were transported smoothly into the discharge column by dissolution of filter on the electrode.

Several combinations of materials of electrodes, on which filters were dissolved and excitation methods were considered. The examined combinations were copper-spark, copper-DC arc, graphite-spark, graphiteDC arc, glassy carbon-spark and glassy carbon-DC arc. As the results, the most strong line intensities were obtained in graphite-DC arc method. And the suitable arc current was 10 amp. from the standpoint of sensitivity and reproducibility.

The influence of co-existed elements on spectral line intensities was also investigated. The spectral lines were intensified as the concentrations of sodium, aluminum, iron, zinc, calcium and magnesium increased, which were the common elements in airborne particulates. But when the optimum amounts of sodium were added to the electrode, the spectral line intensities were almost unaffected by co-existed elements.

From the experimental results above mentioned, a recommendable operating conditions were as follows; a measured volume of air was drawn through a membrane filter $(47 \mathrm{~mm}$ in diameter and 0.8 micron in poresize), on which airborne particulates were collected. A circular disc of $5 \mathrm{~mm}$ in diameter, representing $1.42 \%$ of the total airborne particulates collected, was punched out at randam from the filter. The disc was placed on the flat surface tip of graphite electrode, $6 \mathrm{~mm}$ in diameter, and was dissolved by two drops of methyl-ethyl-ketone. The first drop $(10 \mu l)$ of methyl-ethyl-ketone was dried before adding second drop. A definite volume $(50 \mu l)$ of a internal standard solution, containing $10 \mu \mathrm{g} / \mathrm{ml}$ of cobalt and 4,000 $\mu \mathrm{g} / \mathrm{m} l$ of sodium was added dropwise. Standard electrodes were prepared in the same fashion by dropping standard solutions, containing known amounts of analytical elements, $10 \mu \mathrm{g} / \mathrm{m} l$ of cobalt and $4,000 \mu \mathrm{g} / \mathrm{m} l$ of sodium. The prepared electrodes were subjected to DC arc excitation (current: $10 \mathrm{amp}$., analytical gap: $2 \mathrm{~mm}$, pre-arc time: none and exposure time: $15 \mathrm{sec}$ ).

The proposed method with the minimum procedures for the pretreatments of sample was precise and useful for rapid analysis of trace metals in airborne particulates with coefficient of variation $4.6 \sim 14.4 \%$.

(Received Mar. 6, 1972) 